\title{
ОСНОВНЫЕ ПРОБЛЕМЫ ПРАВОВОГО РЕГУЛИРОВАНИЯ ОТНОШЕНИЙ КОРПОРАТИВНОГО УПРАВЛЕНИЯ В США, ЕС И РОССИЙСКОЙ ФЕДЕРАЦИИ
}

\author{
(C) 2021 Якубов Мухиббулло Лутфуллоевич \\ студент 2-го курса магистратуры \\ Финансовый университет при правительстве РФ, Россия, Москва \\ Старший специалист по финансово правовому анализу ООО МСК «БЛ ГРУПП» \\ E-mail:muhibbullo_97@mail.ru \\ Научный руководитель: к.ю.н., доцент - Дахненко Светлана Сергеевна
}

Автором в настоящей работе рассмотрены и проанализированы проблемы осуществления корпоративного управления корпораций в контексте права США, ЕС, Российской Федерации. Так, на примере регулирования правового статуса членов органов управления в США, автором рассмотрено влияние такой особенности нормативного регулирования, как регулирование корпоративных отношений на уровне штатов, что приводит к определенным противоречиям на уровне государства. Автором также проанализированы используемые в правоприменительной практике инструменты определения недобросовестного поведения лиц.

В отношении законодательства ЕС автором рассмотрена попытка ЕС путем разработки Плана действий по модернизации корпоративного права и улучшения корпоративного управления устранить имеющиеся проблемы и противоречия в корпоративном управлении стран-участников, в т.ч. по вопросу снятия «корпоративной вуали».

Автором проанализированы такие проблемы корпоративного управления в РФ, как осуществление корпоративного управления при наследовании долей в ООО, защита прав добросовестного покупателя долей в ООО.

По итогу работы автором была дана оценка природе проблем, возникающих в процессе правового регулирования корпоративного управления в ЕС, США, Российской Федерации.

Ключевые слова: корпоративное управление, право ЕС, корпоративная вуаль, наследование долей.

Определение основных проблем правового регулирования отношений корпоративного управления призвано обеспечить совершенствование правовой системы. При этом содержание и природа проблем правового регулирования отношений корпоративного управления в США, ЕС и Российской Федерации (далее - РФ) имеют схожую природу, что обусловлено едиными целями регламентации соответствующих отношений.

Одной из основных проблем правового регулирования отношений корпоративного управления в США является наличие различных по своему содержанию нормативных актов на уровне штатов, устанавливающих особенности осуществления корпоративного управления, в том числе особенности статуса органов управления корпорацией, объем их правомочий. Например, данная проблема проявляется при определении статуса независимого директора, членов совета директоров. В частности, Кодекс Штата Делавэр предусматривает достаточно широкую свободу для корпораций по вопросу конкретизации ста- туса членов совета директоров [1]. Такой подход создает определенные основания для злоупотребления со стороны корпораций, что может, в конечном итоге, привезти к недостижению определенных целей функционирования совета директоров. В целом, на федеральном уровне в США установлены критерии определения статуса члена органов управления корпорацией, среди которых отсутствие статуса руководителя или члена исполнительного органа аффилированного лица; отсутствие заинтересованности в какой-либо инвестиционной стратегии юридического лица в целях третьих лиц; не осуществляет отбор кандидатов на позицию независимого директора; не выступает кредитором корпорации и т.д [2]. Важнейшей частью корпоративного управления в системе США является высокая степень добросовестности всех субъектов правоотношений. При этом одной из проблем в указанном процессе является проблема конструкции корпорации, включая аспект имущественной обособленности лица. Механизмом решение представленной проблемы является 
теория «снятия корпоративной вуали», устанавливающая возможность привлечения лица, злоупотребляющего конструкцией юридического лица.

Непосредственно в законодательстве отсутствуют критерии привлечения лиц к ответственности по долгам корпорации (в отличие от отечественной системы субсидиарной ответственности контролирующих лиц). Механизм определения недобросовестности или неразумности реализован исключительно в правоприменительной практике. Так, используется теория «Instrumentality» предполагающая наличие факта использования корпорации для достижения личных целей участников, а также тест Пауэлла, включающий в себя определение отсутствия принципа ограниченной ответственности корпорации. В этой связи используются такие элементы как:

- фактор контроля;

- фактор противоправных действий;

- причинно-следственная связь [3].

Представляется, что перечисленные проблемы регулирования в США обусловлены спецификой англо-саксонской системы и не приводят к резко негативным последствиям. Развитие определенных концепций, в том числе путем совершенствования правоприменительной практики способствует достижению необходимого баланса между регулированием и свобод действий.

Рассматривая проблемы корпоративного управления в ЕС необходимо отметить правовую потребность выработки единых стандартов по целому ряду аспектов корпоративного управления для чего был разработан План действий по модернизации корпоративного права и улучшения корпоративного управления. Как отмечает Н.А.Полежаева «при реализации данной задачи уполномоченные органы ЕС столкнулись с некоторыми затруднениями, в частности с проблемами выработки единых норм для государств-членов ЕС и обоснования компетенции EC по принятию ряда мер. Однако установленные требования о транспарентности позволили обойти эти вопросы. План не регулирует правоотношения по существу, не содержит обязательных правил. Отношения регулируются на уровне участников, что, в свою очередь, способствует их заинтересованности. Также транспарентность обеспечивает защиту участников компаний и третьих лиц, возможность контролировать правомерность определенных действий. Таким образом, транспарентность стала своего рода принципом правового регулирования в сфере корпоративного законодательства ЕС. Вовлечение акционеров в дела компании также свидетельствует об ориентации регулирования на саморегулирование» [4].

В качестве пути разрешения представленной проблемы было выбрано установление возможности стран-участницам ЕС самостоятельно определить правовой режим следующих аспектов:

- поддержание уставного капитала;

- вопросы несостоятельности;

- процедура ликвидации;

- ведение финансовой отчетности [5].

В свою очередь, неоднозначным также остается проблема определения пределов ответственности корпорации в рамках межнационального характера ЕС, включая возможность применения стандартов отдельных государств при разрешении отдельных спорах об исполнении обязательств. Более того, в рамках ЕС существенным образом отличается порядок применения теории «снятия корпоративной вуали» во Франции и Германии. Так, в Германии закрепляется нормативная конструкция привлечения контролирующего лица к субсидиарной ответственности.

Проблемы правоприменительной практики, касающиеся вопросов корпоративного управления в Российской Федерации, а именно статуса участника ООО и акционера в АО, обусловлены достаточно большим количеством положений, регламентирующих процесс осуществления деятельности рассматриваемыми субъектами, а также изменяющейся действительности. Определение основных проблем правоприменительной практики по рассматриваемому вопросу обеспечивает не только определение ключевых аспектов совершенствования законодательства РФ, но также позволяет сформировать единую правоприменительную практику, способствующую разрешению вопросов, связанных с отдельными аспектами статуса участников и акционеров. Прежде всего, актуальной проблемой правоприменительной практики выступает сам факт возникновения статуса участника ООО, а именно вопрос добросовестности приобретателя доли. Так, возникает вопрос об объеме той информации, которую должно изучить лицо перед непосредственно покупкой доли ООО. Согласно сложившемуся подходу суды зачастую не принимают доводы стороны, основанные на 
ссылках на ЕГРЮЛ [6]. По мнению исследователей, подобный подход обусловлен отсутствием защиты приобретателя в ситуации, когда сведения попали в соответствующий реестр на основании фактов, которые не имеют под собой правового обоснования [7]. Исходя из указанного, можно сделать вывод о том, что лицо обязано не только осуществить проверку реестра, но и исследовать целый ряд других обстоятельств, которые предшествовали приобретению доли. Именно поэтому возникают вопросы об объеме подобной информации, которую приобретатель должен изучить перед совершением сделки.

Также одним из актуальных вопросов правоприменительной практики, касающихся статуса участника общества, является аспект наследования долей. В частности, устав общества может содержать положения, предусматривающие переход доли к наследникам участника только при наличии согласия всех участников такого общества. Так, на практике возникла ситуация, когда наследница, проживая за границей, приняла наследство в 2012 году, а свидетельство о праве на наследство получилась лишь в 2015. После получения свидетельства о праве на наследство она обратилась в общество с заявлением об отказе от участия в обществе и выплате действительной стоимости доли. При этом она указала, что в случае принятия ее в состав участников просит предоставить ей учредительные, а также финансовые документы.

В результате участники приняли решение о принятии ее в состав членов ООО, но наследница оспорила в судебном порядке принятое решение (в заявлении она указала на тот факт, что она не хочет быть участницей ООО и просит ей выплатить действительную стоимость доли). По итогам рассмотрения данного дела суд признал вышеприведенное решение общего собрания недействительным и предложил наследнице повторно обратиться в общество с соответствующим заявлением [8]. После вынесенного решения наследница обратилась к обществу с заявлением о включении ее в состав участников ООО. Указанное заявление было удовлетворено, и она стала участником общества. После приобретения статуса участника она проанализировала документы и увидела, что в 2013 году в обществе распределялась прибыль. Данное обстоятельство стало основанием для обращения ее в суд с требованием о выплате, причитающейся ей прибыли. При этом на момент подачи соответствующего заявления в суд финансовые показа- тели юридического лица значительно ухудшились. Суды первой и апелляционной инстанции отказали в удовлетворении заявленных требований ввиду того, что на момент заявленного требования (2016 год) появились обстоятельства, которые не позволяют обществу выплатить заявленную сумму. При этом они указали, что сам факт возникновения прав на распределенную прибыль датируется в момент открытия наследства [9]. В свою очередь, кассационная инстанция и ВС РФ высказали позицию о необходимости оценки обстоятельств, которые препятствуют выплате прибыли, на момент распределения прибыли [10]. Исходя из указанных выводов возникает вопрос о назначении института получения согласия участников ООО для вступления в такое общество. При этом в другом деле ВС РФ приходил к выводу о том, что в случае наличия в уставе общества положения, которое предусматривает обязательное получение согласие других участников на переход доли, моментом возникновения соответствующих прав является именно дата выражения согласия [11]. Более того, ВС РФ в постановлении, посвященном вопросам наследования, указывает, что до момента получения свидетельства о праве на наследство вопрос о вступлении в число участников ООО не может рассматриваться [12].

Анализируя правоприменительные акты, можно отметить, что арбитражные суды прекращают производство по делу в ситуации, когда устанавливают тот факт, что сначала истец, являющийся участником корпорации, оспаривал сделки с заинтересованностью в порядке статьи 45 Закона об ООО, а в последующем обратился в суд по той же самой сделке в порядке пункта 2 статьи 174 ГК РФ [13].

Таким образом, действующая система правового регулирования корпоративного управления в Российской Федерации приводит к возникновению целого ряда вопросов в правоприменительной практике. Более того, неоднозначная позиция судов разных инстанций не позволяет обеспечить единство толкования отдельных аспектов статуса рассматриваемых лиц. Кроме того, на наш взгляд, требуется обеспечить принятие акта толкования ВС РФ, разъясняющего особенности рассмотрения добросовестности приобретателя с целью недопущения ситуаций различного применения норм гражданского и корпоративного законодательства, касающихся вопросов добросовестности приобретения доли в 000 . 


\section{Библиографический список}

1. Магдалинская Ю.В. Особенности правового статуса института независимого директора в законодательных системах США и России // Matters of Russian and International Law. 2018, Vol.7, Is.1A

2. Саликова Н.М., Дубовцев И. А. Особенности трудо-правового статуса независимого директора публичного акционерного общества по российскому и американскому праву//Трудовое правов России и за рубежом. 2016 .№ 3. C.22-25.

3. Ломакин, Д. В. Концепция снятия корпоративного покрова: реализация ее основных положений в действующем законодательстве и проекте изменений Гражданского кодекса РФ // Вестник Высшего Арбитражного Суда Российской Федерации. 2012. № 9.

4. Полежаева Н.А. Модернизация корпоративного законодательства ЕС // Международное публичное и частное право. 2020. N 3. С. 12-15.

5. Павлюк А.В. Проблемы административно-правового регулирования деятельности акционерных обществ в зарубежных государствах // Административное и муниципальное право. 2014. N 5. С. 478-489.

6. Постановление Восемнадцатого АСС от 12.12.2012 № 18АП-11764 по делу № А07-23882/2011// Документ опубликован не был. Источник - СПС КонсультантПлюс.

Постановление АС Московского округа от 16.12.2015 № Ф05-17855/2015 по делу № А40-209621/14 // Документ опубликован не был. Источник - СПС КонсультантПлюс.

7. Карнаков Я.В. Достоверность ЕГРЮЛ и нарушение преимущественного права на покупку доли в ООО: комментарий к Определению Судебной коллегии по экономическим спорам ВС РФ от 28.01.2016 № 309-ЭС1510685 // Вестник экономического правосудия РФ. 2016. № 3.

8. Решение Первомайского районного суда г. Омска от 18.01.2016 по делу № 2-602/2016 // Документ опубликован не был. Источник - СПС КонсультантПлюс.

9. Решение Арбитражного суда Омской области от 02.02.2017 по делу № A46-16046/2016 // Документ опубликован не был. Источник - СПС КонсультантПлюс.

Постановление Восьмого арбитражного апелляционного суда от 30.05.2017 № 08АП-2862/2017 по делу № А46-16046/2016 // Документ опубликован не был. Источник - СПС КонсультантПлюс.

10. Определение ВС РФ от 23.07.2018 N 304-ЭС18-9887 по делу № А46-16046/2016 // Документ опубликован не был. Источник - СПС КонсультантПлюс.

11. Определение ВС РФ от 07.02.2017 N 305-ЭС16-19827 // Документ опубликован не был. Источник - СПС КонсультантПлюс.

12. Постановлении Пленума ВС РФ от 29.05.2012 № 9 «О судебной практике по делам о наследовании» // Российская газета. № 127. 06.06.2012.

13. Постановление Арбитражного суда Северо-Западного округа от 28 ноября $2016 \quad$ г. № Ф07-9845/2016 по делу № А66-6377/2015 // Документ опубликован не был. Источник - СПС КонсультантПлюс. 